\title{
Clinicopathological and prognostic significance of PDCD4 and microRNA-21 in human gastric cancer
}

\author{
KAZUO MOTOYAMA ${ }^{1,2}$, HIROSHI INOUE ${ }^{1}$, KOSHI MIMORI $^{1}$, FUMIAKI TANAKA ${ }^{1}$, KAZUYUKI KOJIMA ${ }^{2}$, \\ HIROYUKI UETAKE ${ }^{2}$, KENICHI SUGIHARA ${ }^{2}$ and MASAKI MORI ${ }^{1,3}$
}

\begin{abstract}
${ }^{1}$ Department of Molecular and Surgical Oncology, Medical Institute of Bioregulation, Kyushu University, 4546 Tsurumibaru, Beppu 874-0838; ${ }^{2}$ Department of Surgical Oncology, Graduate School of Medical and Dental Science, Tokyo Medical and Dental University, 1-5-45 Yushima, Bunkyo-ku, Tokyo 113-8519; ${ }^{3}$ Department of Gastroenterological Surgery, Graduate School of Medicine, Osaka University, 1-1 Yamadaoka, Suita 565-0871, Japan
\end{abstract}

Received September 3, 2009; Accepted October 27, 2009

DOI: 10.3892/ijo_00000590

\begin{abstract}
Recent studies have demonstrated that the novel tumor suppressor protein programmed cell death 4 (PDCD4) is downregulated in several human solid cancer types and is suppressed by microRNA-21 (miR-21). The objectives of this study were: i) to establish the clinicopathological and prognostic significance of $P D C D 4 \mathrm{mRNA}$, and ii) to elucidate any correlation between PDCD4 mRNA and miR-21 in gastric cancer. The expression status of PDCD4 mRNA was investigated by qRT-PCR and protein expression was analyzed by an immunohistochemical study. We analyzed PDCD4 mRNA expression with respect to various clinicopathological factors in 105 gastric cancers. We also performed an association study comparing PDCD4 mRNA and miR-21 in eight cell lines and 49 gastric cancers. Expression of $P D C D 4$ mRNA in cancer tissues was significantly lower than in non-cancer tissues $(\mathrm{P}<0.05)$. Patients with low PDCD4 mRNA expression was significantly correlated with size, depth, lymph node metastasis, venous invasion, advanced stage, and poor clinical prognosis $(\mathrm{P}<0.05)$. Expression of miR-21 in cancer tissues was significantly higher than in non-cancer tissues $(\mathrm{P}<0.05)$. Elevated miR-21 expression was significantly correlated with size and depth $(\mathrm{P}<0.05)$. An inverse correlation between PDCD4 mRNA and miR-21 was found in gastric cancer. This study revealed that low PDCD4 expression correlates with biological aggressiveness and poor prognosis in gastric cancer. Furthermore, our findings suggest that $P D C D 4 \mathrm{mRNA}$ is negatively regulated by miR-21 in gastric cancer and may serve as a target for effective therapies.
\end{abstract}

Correspondence to: Dr Masaki Mori, Department of Gastroenterological Surgery, Graduate School of Medicine, Osaka University, 1-1 Yamadaoka, Suita 565-0871, Japan

E-mail: mmori@gesurg.med.osaka-u.ac.jp

Key words: gastric cancer, microRNA, PDCD4, miR-21, prognosis

\section{Introduction}

Programmed cell death 4 (PDCD4) was first identified as a gene that is up-regulated upon induction of apoptosis in murine cell lines (1). Since then, several studies have gained insight into PDCD4 function by identifying binding partners and regulatory elements involved in tumorigenesis. PDCD4 has been characterized as a novel tumor suppressor gene that inhibits tissue polypeptide antigen (TPA)-induced neoplastic transformation $(2,3)$ and tumor promotion/progression in a transgenic mice (4). Supporting evidence was provided by Schmid and colleagues who demonstrated that activation of both PI3K and MEK/ERK signaling is required to maintain downregulation of PDCD4 by TPA in tumorigenesis (5). The molecular basis for PDCD4-mediated suppression has been linked to its high affinity MA-3 domains that sequester the eukaryotic translation initiation factors eIF4A and eIF4G to inhibit protein synthesis (6-9).

Furthermore, PDCD4 plays a key role in suppressing tumorigenesis by regulating several other genes involved in multiple processes including, apoptosis, cell cycle, and cell proliferation. Among these proteins regulated by PDCD4 are p21 (10), CDK4, ornithine decarboxylase (4), carbonic anhydrase II (11), JNK/c-Jun/AP-1 $(12,13)$ and u-PAR (14). Additionally, PDCD4 has been shown to be regulated by a diverse set of molecules affecting several pathways including topoisomerase-inhibitors (15), COX-2-inhibitors (16), v-Myb (17), Akt $(18,19)$ and mitogens (20).

PDCD4 is ubiquitously expressed in human tissues. Several studies observed loss of PDCD4 expression in various human solid neoplasias $(19,21-24)$. These reduced PDCD4 levels have proven to be a poor prognostic factor in several human cancers $(19,21,24,25)$. To our knowledge, however, the clinicopathological and prognostic values of PDCD4 expression have not been thoroughly investigated in human gastric cancer.

MicroRNAs (miRNAs) are a class of mature non-coding small RNA-21-25 nucleotides that have been implicated in diverse cellular processes including development, differentiation, proliferation, migration, and apoptosis $(26,27)$. They target protein-coding mRNAs at the post-transcriptional level by direct cleavage of the mRNA or by inhibition of protein 
synthesis $(28,29)$. Recent evidence indicates that some miRNAs can function as oncogenes or tumor suppressors (29).

Overexpression of oncogenic miR-21 has been reported in several types of human malignant solid tumors (30-35). Furthermore, recent studies demonstrate that miR-21 promotes carcinogenesis through inhibition of apoptosis, proliferation, invasion, migration, and metastasis (32-34,36$38)$. Recently, several studies revealed that PDCD4 is negatively regulated by miR-21 in pancreatic tumors (31), colon cancer $(36)$, breast cancer $(37,39)$ and in glioblastoma cell lines (40). To our knowledge, there are no reports on a possible correlation between PDCD4 and miR-21 in gastric cancer.

In this study, we investigated the expression of PDCD4 in 105 tumor samples to determine its clinicopathological and prognostic value. We also investigated possible associations between PDCD4 mRNA and miR-21 expression levels in patient samples and established gastric cancer cell lines.

\section{Materials and methods}

Tissue samples and cell lines. One hundred and five gastric tumor samples and matched controls in the experimental panel were obtained from the Department of Molecular and Surgical Oncology, Medical Institute of Bioregulation, Kyushu University, Beppu, Japan. All samples were derived from patients who had not received adjuvant treatment including radiotherapy or chemotherapy prior to surgery in order to eliminate potential treatment-induced changes to gene expression profiles. Immediately following surgical resection, tissues were frozen in liquid nitrogen and kept at $-90^{\circ} \mathrm{C}$ until RNA extraction. Written informed consent was obtained from all patients according to the guidelines approved by the Institutional Research Board, and this study was conducted under the supervision of the ethics board of Kyushu University. The follow-up periods ranged from 0.1 to 11.2 years with a mean of 2.5 years. Human gastric carcinoma cell lines MKN1, MKN7, MKN45, MKN74, NUGC3, NUGC4, AZ521, and KATOIII were obtained from the Cell Resource Center for Biomedical Research Institute of Development, Aging and Cancer (Tohoku University, Sendai, Japan) and maintained according to recommended protocols.

$R N A$ preparation for reverse transcription-PCR. Total RNA was isolated by the modified acid guanidinium-phenol chloroform procedure (41).

Quantitative real-time reverse transcription-PCR. Complementary DNA (cDNA) was synthesized from $8 \mu \mathrm{g}$ of total RNA using random hexamer primers and M-MLV reverse transcriptase (Invitrogen, Carlsbad, CA, USA) as described previously (42). The primers for PDCD4 amplification (NM_014456) were as follows: sense 5'-GTATGATGTGG AGGAGGTGGAT-3' and antisense 5'-CCCTCCAATGCTA AGGATACTG-3'. The primers for $G A P D H$ were as follows: sense primer 5'-TTGGTATCGTGGAAGGACTCA-3' and antisense primer 5'-TGTCATCATATTTGGCAGGTT-3' (43).

PCR amplifications for quantification of PDCD4 and $G A P D H$ mRNA were done in a LightCycler system (Roche Applied Science, Indianapolis, IN, USA) using the LightCycler
FastStart DNA Master SYBR Green I kit (Roche Diagnostics, Mannheim, Germany). In brief, a master mixture was prepared on ice, containing $1 \mu \mathrm{l}$ of cDNA, $2 \mu \mathrm{l}$ of LC DNA Master SYBR Green I mix, $50 \mathrm{ng}$ of primers, and $2.4 \mu 1$ of $25 \mathrm{nmol} / 1$ $\mathrm{MgCl}_{2}$. The amplification conditions for 35 cycles consisted of denaturation at $95^{\circ} \mathrm{C}$ for $10 \mathrm{sec}$, annealing at $65^{\circ} \mathrm{C}$ for $10 \mathrm{sec}$, and extension at $72^{\circ} \mathrm{C}$ for $10 \mathrm{sec}$. The products were then subjected to a temperature gradient from $68^{\circ} \mathrm{C}$ to $95^{\circ} \mathrm{C}$ at $0.1^{\circ} \mathrm{C} / \mathrm{sec}$, with continuous fluorescence monitoring to produce melting curves of the products. The expression levels were normalized to GAPDH mRNA expression (44).

Quantitative real-time reverse transcriptase-PCR for miRNA. Total RNA was extracted from cell lines and tissue samples of gastric cancer using TRIzol (Invitrogen) as per the manufacturer's protocol. The miR-21 and RNU6B (as an internal control) -specific cDNA were synthesized from total RNA using gene-specific primers according to the TaqMan MicroRNA assays protocol (Applied Biosystems, Foster City, CA, USA). Reverse transcriptase reactions contained $10 \mathrm{ng}$ of total RNAs, $50 \mathrm{nmol} / \mathrm{l}$ stem-loop RT primer, 1X RT buffer, $0.25 \mathrm{mmol} / \mathrm{l}$ each of deoxynucleotide triphosphate (dNTP), $3.33 \mathrm{U} / \mu 1$ MultiScribe reverse transcriptase, and $0.25 \mathrm{U} / \mu 1 \mathrm{RNase}$ Inhibitor. The 7.5- $\mu 1$ reaction volumes were incubated in Bio-Rad i-Cycler (Bio-Rad Laboratories, Hercules, CA, USA) in a 96-well plate for $30 \mathrm{~min}$ at $16^{\circ} \mathrm{C}$, $30 \mathrm{~min}$ at $42^{\circ} \mathrm{C}, 5 \mathrm{~min}$ at $85^{\circ} \mathrm{C}$, and then held at $4^{\circ} \mathrm{C}$.

Real-time PCR was performed using an Applied Biosystems 7500 real-time PCR system. The 10- $\mu 1$ PCR included $0.67 \mu \mathrm{l}$ of RT products, 1X TaqMan Universal PCR master mix, and $1 \mu \mathrm{l}$ of primers and probe mix of the TaqMan MicroRNA Assays. The reactions were incubated in 96-well optical plates at $95^{\circ} \mathrm{C}$ for $10 \mathrm{~min}$ and then followed by 45 cycles of $95^{\circ} \mathrm{C}$ for $15 \mathrm{sec}$ and $60^{\circ} \mathrm{C}$ for $10 \mathrm{~min}$. Relative quantification of miRNA expression was calculated using the $2^{-\Delta \Delta C t}$ method. The raw data were presented as the relative quantity of target miRNA, normalized with respect to RNU6B, and relative to a calibrator sample.

In situ hybridization for PDCD4 protein detection. Immunohistochemical studies of PDCD4 protein were done on surgical specimens from 5 selected gastric cancer patients using the avidin-biotin-peroxidase method (LSAB2 kit; Dako, Kyoto, Japan) on formalin-fixed, paraffin-embedded tissues. After deparaffinization and blocking, the antigen-antibody reaction was carried out overnight at $4^{\circ} \mathrm{C}$. The LSAB2 kit was applied to detect the signal of the PDCD4 antigen-antibody reaction. The rabbit polyclonal antibody against human PDCD4 (Rockland Immunochemicals, Inc., Gilbertsville, PA, USA) was used at 1:500.

Statistical analysis. Biostatistical analyses were performed with JMP 5.0.1a for Windows software (SAS Institute, Cary, NC, USA). Possible differences between groups were analyzed using Student's t-test and Chi-square $\left(\chi^{2}\right)$ test. The association between expression levels of PDCD4 mRNA and miR-21 was analyzed by Spearman correlation coefficient. Survival curves were obtained by the Kaplan-Meier method (45), comparison between curves was made by log-rank test. A probability level of 0.05 was chosen for statistical significance. 

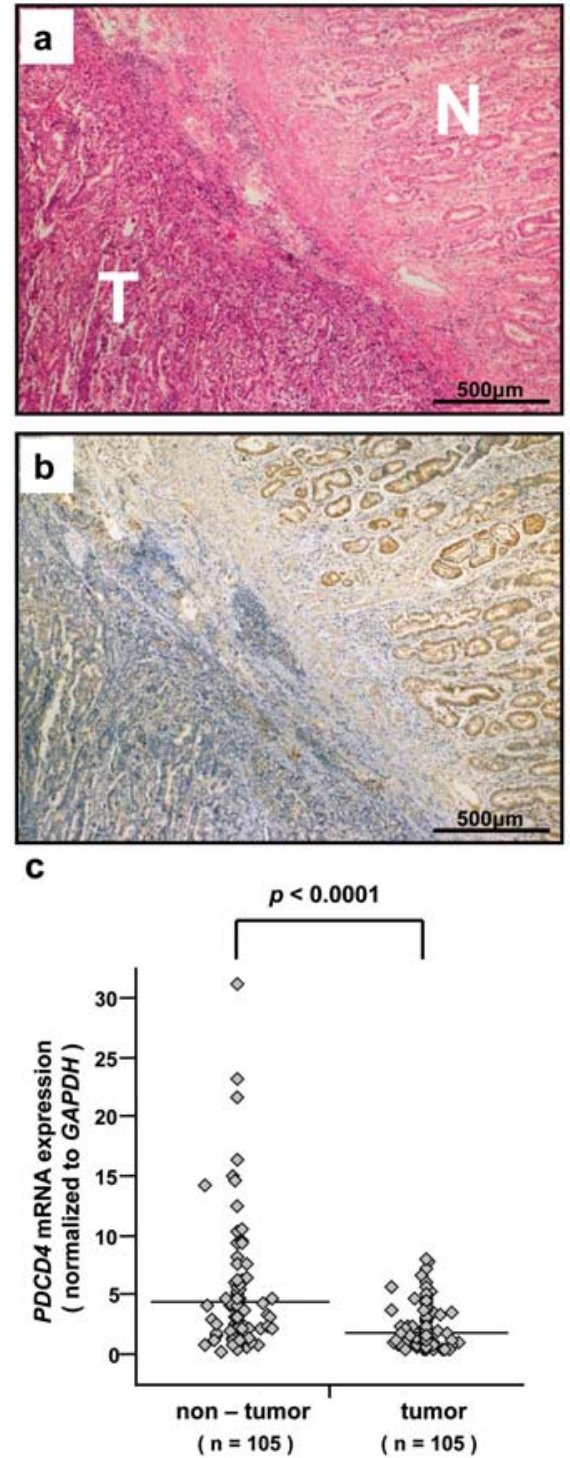

Figure 1. Detection of PDCD4 protein expression in representative examples of gastric cancer by in situ hybridization (a and b). Original magnification x40, H\&E staining (a), original magnification x40, PDCD4 staining (b), quantitative real-time RT-PCR analysis of PDCD4 mRNA in tumor and non-tumor samples of 105 gastric cancer cases (c). Horizontal lines indicate mean value of each sample.

\section{Results}

PDCD4 mRNA and protein expression is lower in primary gastric cancer tissues. We performed in situ hybridization on representative formalin-fixed, paraffin-embedded tissues in order to visualize expression of PDCD4 protein in gastric cancer and adjacent normal tissues (Fig. 1). H\&E staining highlights apparent differences between gastric tumor and normal epithelium in primary tissue samples (Fig. 1a). More importantly, we probed tissue samples with an anti-PDCD4 antibody to show that PDCD4 protein levels are markedly lower in gastric tumor than adjacent normal tissue (Fig. 1b), where highest PDCD4 concentrations are primarily localized in the nucleus and the cytoplasm.

In order to corroborate this observation, we examined 105 primary patient samples for PDCD4 mRNA levels by quantitative real-time reverse transcriptase-PCR (qRT-PCR) to assess differential expression within tissues. After norma-
Table I. Clinicopathological data and PDCD4 mRNA expression in 105 gastric cancers.

\begin{tabular}{|c|c|c|c|}
\hline \multirow[b]{2}{*}{$\begin{array}{l}\text { Clinicopathologic } \\
\text { variables }\end{array}$} & \multicolumn{2}{|c|}{$\begin{array}{l}\text { PDCD4 mRNA } \\
\text { expression }\end{array}$} & \multirow[b]{2}{*}{ P-value } \\
\hline & $\begin{array}{c}\mathrm{T}<\mathrm{N} \\
(\mathrm{n}=77)\end{array}$ & $\begin{array}{c}\mathrm{T}>\mathrm{N} \\
(\mathrm{n}=28)\end{array}$ & \\
\hline \multicolumn{4}{|l|}{ Size (cm) } \\
\hline$\geq 5$ & 29 & 18 & $0.02^{\mathrm{a}}$ \\
\hline$<5$ & 48 & 10 & \\
\hline \multicolumn{4}{|l|}{ Histological type } \\
\hline Well & 13 & 7 & 0.09 \\
\hline Moderately & 22 & 10 & \\
\hline Poorly & 33 & 7 & \\
\hline Signet & 4 & 4 & \\
\hline Mucinus & 5 & 0 & \\
\hline \multicolumn{4}{|l|}{ Depth } \\
\hline $\mathrm{m}, \mathrm{sm}, \mathrm{mp}$ & 20 & 17 & $<0.01^{\mathrm{a}}$ \\
\hline ss, se, si & 57 & 11 & \\
\hline \multicolumn{4}{|c|}{ Lymph node metastasis } \\
\hline Absent & 24 & 16 & $0.02^{\mathrm{a}}$ \\
\hline Present & 53 & 12 & \\
\hline \multicolumn{4}{|c|}{ Lymphatic invasion } \\
\hline Absent & 20 & 11 & 0.19 \\
\hline Present & 57 & 17 & \\
\hline \multicolumn{4}{|l|}{ Venous invasion } \\
\hline Absent & 52 & 25 & $0.02^{\mathrm{a}}$ \\
\hline Present & 25 & 3 & \\
\hline \multicolumn{4}{|l|}{ Liver metastasis } \\
\hline Absent & 73 & 28 & 0.11 \\
\hline Present & 4 & 0 & \\
\hline \multicolumn{4}{|c|}{ Peritoneal dissemination } \\
\hline Absent & 62 & 26 & 0.11 \\
\hline Present & 15 & 2 & \\
\hline \multicolumn{4}{|l|}{ Stage } \\
\hline I, II & 35 & 20 & $0.02^{\mathrm{a}}$ \\
\hline III, IV & 42 & 8 & \\
\hline
\end{tabular}

${ }^{\mathrm{a}} \mathrm{P}<0.05$.

lization to GAPDH gene expression levels, the majority of patient tissues, 77 of 105 (77.3\%), showed a lower expression level of PDCD4 mRNA in tumor than in non-tumor tissues. Additionally, the mean $( \pm \mathrm{SD})$ expression level of PDCD4 mRNA was significantly lower in tumor tissues $(1.82 \pm 1.77)$ than in non-tumor tissues $(4.22 \pm 5.03)(\mathrm{P}<0.0001$, Fig. 1c).

Low PDCD4 mRNA expression group correlates with clinicopathological variables and poor prognosis. In order to assess correlations between PDCD4 mRNA values and standard clinicopathological variables listed in Table I, the 105 clinical 


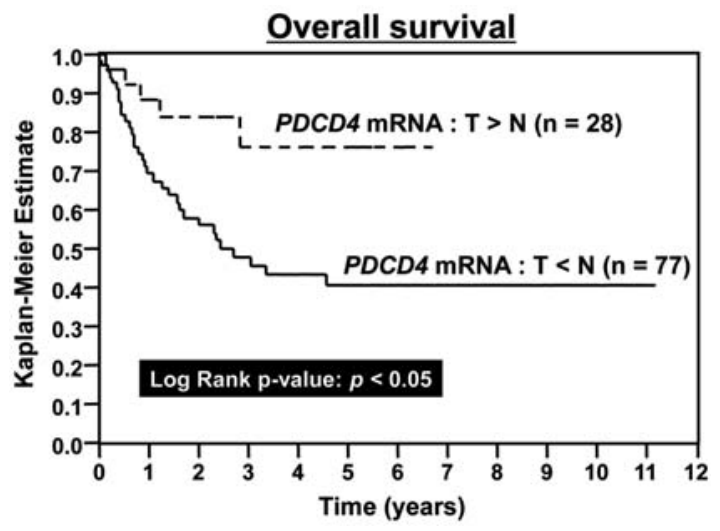

Figure 2. Overall survival rates of clinical cases tested are presented using Kaplan-Meier estimates. The 105 clinical cases were divided into two groups: low PDCD4 group $(\mathrm{T}<\mathrm{N}, \mathrm{n}=77)$ in which the expression levels of $P D C D 4$ mRNA were lower in tumor than in non-tumor tissues and high PDCD4 group $(\mathrm{T}>\mathrm{N}, \mathrm{n}=28)$ in which the expression levels of PDCD4 mRNA were higher in tumor than in non-tumor tissues.

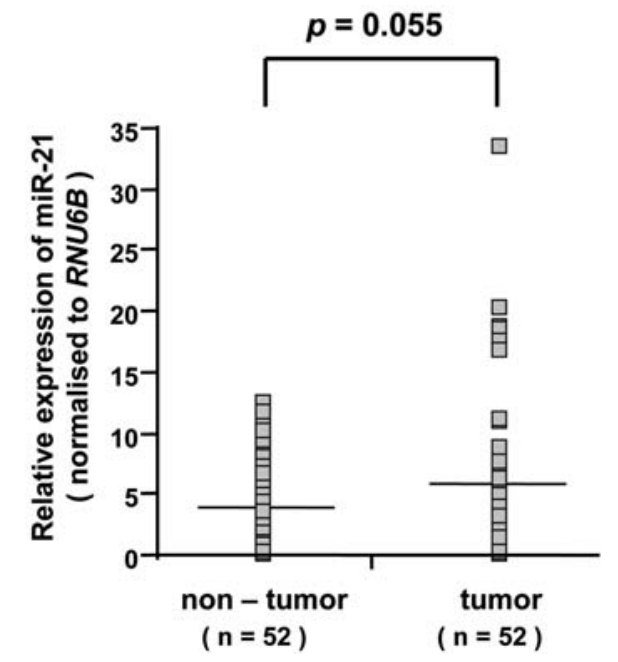

Figure 3. Quantitative real-time reverse transcriptase-PCR analysis of miR-21 expression in clinical samples of gastric cancer patients. Fifty-two tissue gastric tumor and non-tumor samples were selected. MiR-21 expression levels were normalized to RNU6B as an internal standard. Horizontal lines indicate mean value of each sample.

cases were divided into two groups: the low PDCD4 group $(\mathrm{T}<\mathrm{N}, \mathrm{n}=77)$ in which the expression levels of PDCD4 mRNA were lower in tumor than in non-tumor tissues and the high $P D C D 4$ group $(\mathrm{T}>\mathrm{N}, \mathrm{n}=28)$ in which the expression levels of $P D C D 4$ mRNA were higher in tumor than in non-tumor tissues. Table I shows the correlation between expression of PDCD4 mRNA and the clinicopathological data of the 105 gastric cancer patients. The low PDCD4 group was significantly associated with tumor size $(<5 \mathrm{~cm})$, depth (ss, se, si), lymph node metastasis (present), venous invasion (present), and advanced stage (III, IV) $(\mathrm{P}=0.02,<0.01,0.02$, 0.02 and 0.02 , respectively). On the other hand, no significant differences were observed regarding histological type, lymphatic invasion, liver metastasis or peritoneal dissemination. Moreover, by log-rank test, patients in the low $P D C D 4$ group showed significantly poorer prognosis than those in the high PDCD4 group $(\mathrm{P}<0.05$, Fig. 2$)$.
Table II. Clinicopathological data and miR-21 expression in 49 gastric cancers.

\begin{tabular}{|c|c|c|c|}
\hline \multirow[b]{2}{*}{$\begin{array}{l}\text { Clinicopathologic } \\
\text { variables }\end{array}$} & \multicolumn{2}{|c|}{ miR-21 expression } & \multirow[b]{2}{*}{ P-value } \\
\hline & $\begin{array}{l}\text { High } \\
(n=24)\end{array}$ & $\begin{array}{l}\text { Low } \\
(n=25)\end{array}$ & \\
\hline
\end{tabular}

Size $(\mathrm{cm})$
$\geq 3$
$<3$

$\begin{array}{rrr}1 & 9 & <0.01^{\mathrm{a}} \\ 23 & 16 & \end{array}$

Histological type

$\begin{array}{lrr}\text { Well } & 4 & 3 \\ \text { Moderately } & 11 & 5 \\ \text { Poorly } & 7 & 13 \\ \text { Signet } & 1 & 3 \\ \text { Mucinus } & 1 & 1 \\ \text { Depth } & & \end{array}$

$\begin{array}{lrrr}\text { m, sm, mp } & 3 & 12 & <0.01^{\text {a }} \\ \text { ss, se, si } & 21 & 13 & \end{array}$

Lymph node metastasis

$\begin{array}{llll}\text { Absent } & 6 & 12 & 0.09\end{array}$

$\begin{array}{lll}\text { Present } & 18 & 13\end{array}$

Lymphatic invasion

$\begin{array}{lrrr}\text { Absent } & 3 & 8 & 0.09 \\ \text { Present } & 21 & 17 & \\ \text { Venous invasion } & & & \\ \text { Absent } & 17 & 17 & 0.82 \\ \text { Present } & 7 & 8 & \end{array}$

Liver metastasis

Absent $22 \quad 25$

0.08

Present

20

Peritoneal dissemination

\begin{tabular}{lrrr} 
Absent & 20 & 21 & 0.95 \\
Present & 4 & 4 & \\
Stage & & & \\
I, II & 12 & 14 & 0.67 \\
III, IV & 12 & 11 & \\
\hline
\end{tabular}

${ }^{\mathrm{a}} \mathrm{P}<0.05$

Expression of miR-21 in clinical samples and clinicopathological characteristics. We performed qRT-PCR on 52 selected specimens to evaluate miR-21 expression in clinical samples of gastric cancer patients, and found that 34 of $52(65.4 \%)$ showed a higher expression level of miR-21 in tumor than in non-tumor tissues. As shown in Fig. 3, after normalization to RNU6B expression levels, the mean $( \pm \mathrm{SD})$ expression level of miR-21 was higher in tumor tissues $(5.92 \pm 6.41)$ than in non-tumor tissues $(3.97 \pm 3.41)(\mathrm{P}=0.055)$. Based upon these elevated miR-21 expression levels and the knowledge that PDCD4 mRNA correlated to tumor size, etc., we selected 49 clinical cases to evaluate miR-21/clinico- 
a
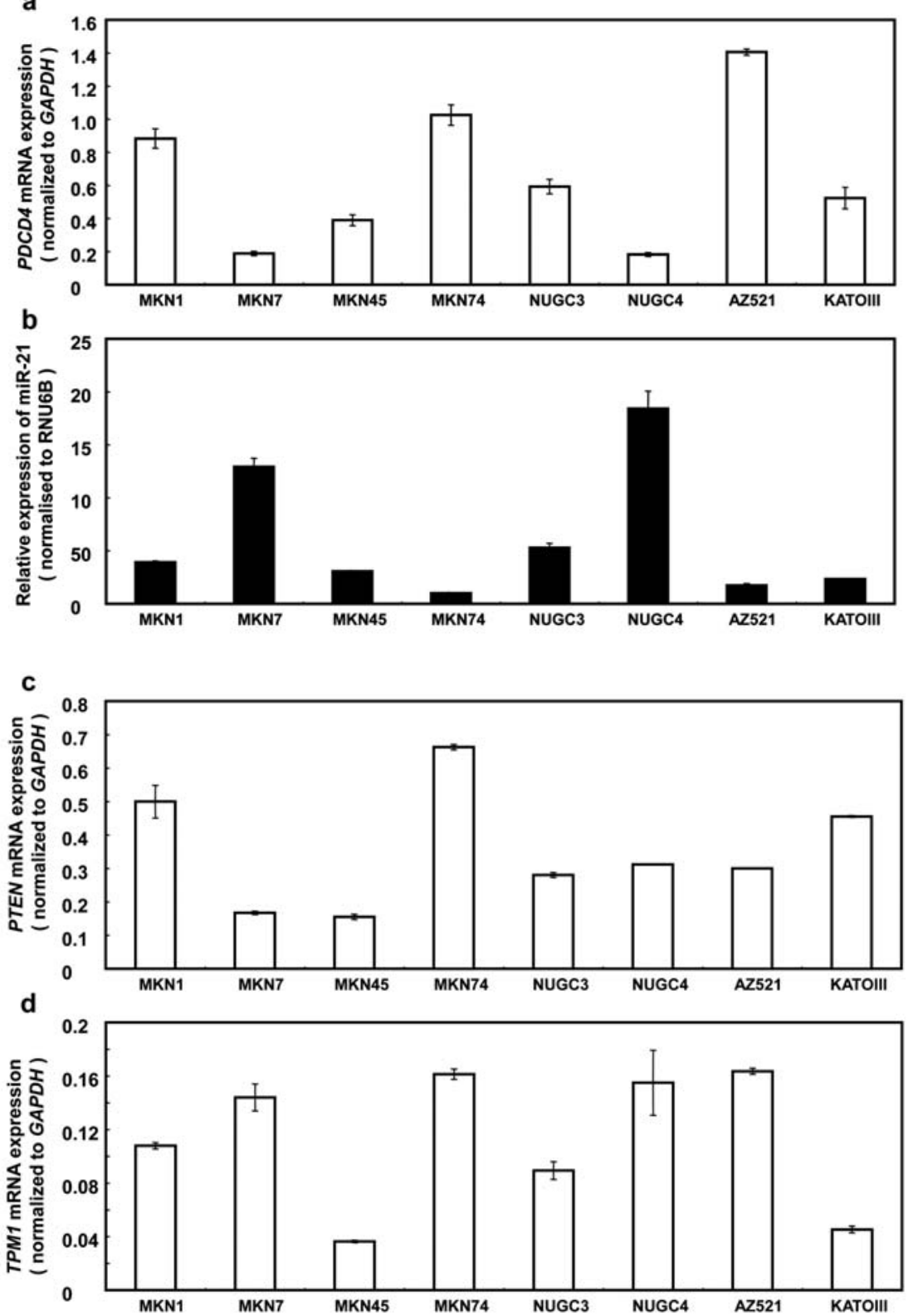

e

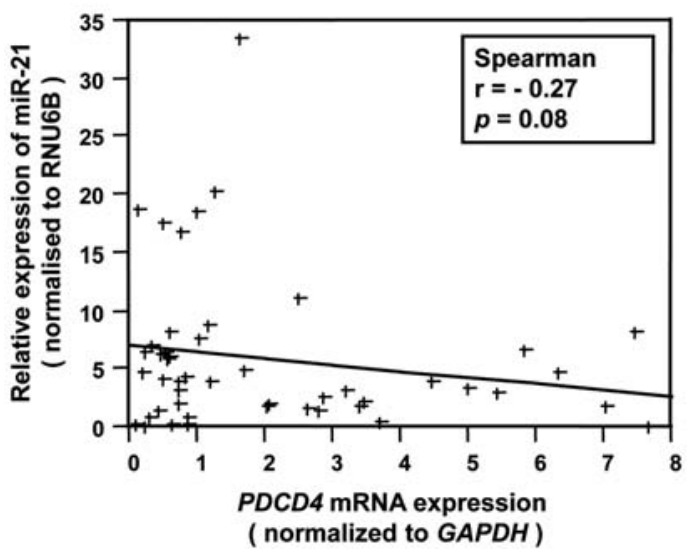

Figure 4. Quantitative real-time reverse transcriptase-PCR analysis and correlation data between $P D C D 4$ mRNA and miR-21 in a panel of eight gastric cancer cell lines. PDCD4 mRNA and miR-21 levels were normalized to $G A P D H$ and RNU6B, respectively, as internal standards (a and b). Expression of PTEN mRNA and TPM1 mRNA was normalized to GAPDH in the same afore-mentioned gastric cancer cell lines (c and d). Relationship between PDCD4 mRNA and miR-21 in gastric cancer patients is plotted in (e). pathological variable correlations. In order to perform the correlation analysis, we divided the 49 patients into two groups: the high miR-21 group $(n=24)$ and the low miR-21 group $(n=25)$. As shown in Table II, the high miR-21 group was significantly associated with tumor size $(<3 \mathrm{~cm})$ and depth (ss, se, si) $(\mathrm{P}<0.01)$. On the other hand, no significant differences were observed regarding histological type, lymph node metastasis, lymphatic invasion, venous invasion, liver metastasis, peritoneal dissemination, advanced stage (III, IV) or prognosis (data not shown).

PDCD4 mRNA expression inversely correlates with miR-21 expression in gastric cancer cell lines and gastric cancers. To evaluate the correlation between PDCD4 mRNA and miR-21, we analyzed PDCD4 mRNA and miR-21 in gastric cancer cell lines (MKN1, MKN7, MKN45, MKN74, NUGC3, NUGC4, AZ521, and KATOIII). As shown in Fig. 4a and b, we found an inverse correlation between PDCD4 mRNA and miR-21 in gastric cancer cell lines $(\mathrm{P}<0.05)$. On the other 
hand, no significant correlations between PTEN mRNA or TPM1 mRNA and miR-21 were observed (Fig. 4c and d), though previous studies reported that identified targets for miR-21 include PTEN $(32,33)$ and TPM1 (46).

We then surveyed miR-21 expression in 49 out of 105 gastric cancers in which expression levels of PDCD4 mRNA were analyzed. As shown in Fig. 4e, we found an inverse correlation between PDCD4 mRNA and miR-21 in 49 clinical gastric cancer patients (Spearman's correlation coefficient $=$ $-0.26, \mathrm{P}=0.08)$.

\section{Discussion}

In this study, we demonstrated through a panel of primary specimens and cell culture models that PDCD4 mRNA/ protein expression is lower in gastric cancer tissues compared to corresponding normal tissues (Fig. 1b and c). Previous studies have reported that reduced PDCD4 expression was found in various human solid tumors including primary lung cancer (21), primary pancreatic cancer (22), glioma (23), colon cancer (19) and ovarian cancer (24). However, to our knowledge, there are no reports concerning the clinicopathological significance of reduced PDCD4 expression in gastric cancer. Thus, we studied PDCD4 mRNA expression with respect to various clinicopathological factors in 105 gastric cancer patients.

PDCD4 has been reported as a suppressor of transformation $(2,3)$, tumorigenesis and progression (4), invasion and metalloproteinase activation (13) and an inducer of apoptosis $(1,16)$. Leupold et al demonstrated that PDCD4 inhibits invasion and intravasation by inhibiting the invasion- and progressionrelated molecule u-PAR (14). These observations supported our findings that loss of PDCD4 mRNA expression in gastric cancer tissues was significantly associated with parameters of pathological aggressiveness such as tumor size, depth, lymph node metastasis, venous invasion, and advanced stage (Table I). To our knowledge, this is the first study to link diminished PDCD4 expression to gastric carcinogenesis.

We also found that the underexpression of PDCD4 mRNA in gastric cancer patients was significantly associated with poor prognosis and low overall survival (Fig. 2). Reduced PDCD4 is a negative prognostic factor in primary lung cancer (21), colon cancer (19), ovarian cancer (24) and glioma (25), suggesting that PDCD4 might be a critical indicator for the prediction of survival in patients with gastric cancer.

Overexpression of miR-21 has been reported in several human malignant solid tumors (30-35), supporting our results that expression of miR-21 in gastric cancer tissues was higher than in non-cancer tissues. MiR-21 is one of the most prominent miRNAs implicated in the genesis and progression of human cancer. Increased expression of miR-21 has been related to various processes involved in carcinogenesis, including inhibition of apoptosis (30), promotion of cell proliferation (31), stimulation of tumor growth (34) and chemoresistance (32). Recently, Zhu et al demonstrated that suppression of miR-21 reduced invasion in a breast cancer cell line (38), consistent with our results that overexpression of miR-21 was significantly associated with parameters of pathological aggressiveness such as tumor size and depth (Table II).
There have been a number of reports of PDCD4 as a target of miR-21 $(31,36,37,39,40)$. We thus investigated whether PDCD4 mRNA was negatively regulated by miR-21 in gastric cancer. As shown in Fig. 4, we found an inverse relationship between PDCD4 mRNA and miR-21 in eight gastric cancer cell lines and 49 clinical gastric cancer samples.

MiRNAs have been reported to exert their biologic effects by targeting specific mRNAs in two different ways: i) direct cleavage of the target mRNA using interference machinery (mRNA cleavage), and ii) inhibition of protein synthesis (translational repression) (29). An inverse correlation between PDCD4 mRNA and miR-21 was reported in pancreatic tumors (31) and the MCF-7 breast cancer cell line (39), supporting our results that $P D C D 4$ mRNA was negatively regulated by miR-21 in gastric cancer. In addition, a correlation between PDCD4 mRNA and miR-21 was found in colon cancer cell lines and tissues (36). However, no significant correlation between PDCD4 mRNA and miR-21 was reported in glioblastoma cell lines (40). The molecular mechanism for the relationship between PDCD4 and miR-21 is not yet clear. However, it may indicate different and potentially tissuespecific roles. To the best of our knowledge, this is the first report showing a correlation between PDCD 4 mRNA and miR-21 in gastric cancer.

In conclusion, the present study shows that PDCD4 is a new gastric cancer-related gene and loss of PDCD4 is associated with biological aggressiveness and poor prognosis in gastric cancer. Furthermore, our findings indicate that increased miR-21 is associated with biological aggressiveness and miR-21 may regulate PDCD4 mRNA negatively in human gastric cancer. The results of our study add further support to the expectation that elevating PDCD4 expression, inhibitory strategies against miR-21, or strategies interfering with the PDCD4/miR-21 interaction, offer promising possibilities for treatment of gastric cancer.

\section{Acknowledgments}

We thank T. Shimooka, K. Ogata, M. Kasagi, and Y. Nakagawa for excellent technical assistance. Grant support: Core Research for Evolutional Science and Technology (CREST), Japan Science and Technology Agency (JST); Grant-in-Aid for Scientific Research, Grant numbers 17109013, 18390367, 18590333, 18659384, 18890133, 18015039, 19390336, and 19591509.

\section{References}

1. Shibahara K, Asano M, Ishida Y, Aoki T, Koike T and Honjo T: Isolation of a novel mouse gene MA-3 that is induced upon programmed cell death. Gene 166: 297-301, 1995.

2. Cmarik JL, Min H, Hegamyer G, et al: Differentially expressed protein Pdcd4 inhibits tumor promoter-induced neoplastic transformation. Proc Natl Acad Sci USA 96: 14037-14042, 1999.

3. Yang HS, Jansen AP, Nair R, et al: A novel transformation suppressor, Pdcd4, inhibits AP-1 transactivation but not NF-kappaB or ODC transactivation. Oncogene 20: 669-676, 2001.

4. Jansen AP, Camalier CE and Colburn NH: Epidermal expression of the translation inhibitor programmed cell death 4 suppresses tumorigenesis. Cancer Res 65: 6034-6041, 2005.

5. Schmid T, Jansen AP, Baker AR, Hegamyer G, Hagan JP and Colburn NH: Translation inhibitor Pded4 is targeted for degradation during tumor promotion. Cancer Res 68: 1254-1260, 2008. 
6. Yang HS, Jansen AP, Komar AA, et al: The transformation suppressor Pdcd4 is a novel eukaryotic translation initiation factor 4A binding protein that inhibits translation. Mol Cell Biol 23: 26-37, 2003.

7. Yang HS, Cho MH, Zakowicz H, Hegamyer G, Sonenberg N and Colburn NH: A novel function of the MA-3 domains in transformation and translation suppressor Pdcd4 is essential for its binding to eukaryotic translation initiation factor 4A. Mol Cell Biol 24: 3894-3906, 2004.

8. Zakowicz H, Yang HS, Stark C, Wlodawer A, Laronde-Leblanc N and Colburn NH: Mutational analysis of the DEAD-box RNA helicase eIF4AII characterizes its interaction with transformation suppressor Pded4 and eIF4GI. RNA 11: 261-274, 2005.

9. Suzuki C, Garces RG, Edmonds KA, et al: PDCD4 inhibits translation initiation by binding to eIF4A using both its MA3 domains. Proc Natl Acad Sci USA 105: 3274-3279, 2008.

10. Goke R, Barth P, Schmidt A, Samans B and Lankat-Buttgereit B: Programmed cell death protein 4 suppresses CDK1/cdc2 via induction of p21(Waf1/Cip1). Am J Physiol Cell Physiol 287: C1541-C1546, 2004

11. Lankat-Buttgereit B, Gregel C, Knolle A, Hasilik A, Arnold R and Goke R: Pdcd4 inhibits growth of tumor cells by suppression of carbonic anhydrase type II. Mol Cell Endocrinol 214: 149-153, 2004.

12. Bitomsky N, Bohm M and Klempnauer KH: Transformation suppressor protein Pdcd4 interferes with JNK-mediated phosphorylation of c-Jun and recruitment of the coactivator p300 by c-Jun. Oncogene 23: 7484-7493, 2004.

13. Yang HS, Matthews CP, Clair T, et al: Tumorigenesis suppressor Pdcd4 down-regulates mitogen-activated protein kinase kinase kinase kinase 1 expression to suppress colon carcinoma cell invasion. Mol Cell Biol 26: 1297-1306, 2006.

14. Leupold JH, Yang HS, Colburn NH, Asangani I, Post S and Allgayer H: Tumor suppressor Pdcd4 inhibits invasion/intravasation and regulates urokinase receptor (u-PAR) gene expression via Sp-transcription factors. Oncogene 26: 4550-4562, 2007.

15. Onishi Y, Hashimoto $\mathrm{S}$ and Kizaki H: Cloning of the TIS gene suppressed by topoisomerase inhibitors. Gene 215: 453-459, 1998.

16. Zhang $\mathrm{Z}$ and DuBois RN: Detection of differentially expressed genes in human colon carcinoma cells treated with a selective COX-2 inhibitor. Oncogene 20: 4450-4456, 2001

17. Schlichter U, Burk O, Worpenberg S and Klempnauer KH: The chicken Pdcd 4 gene is regulated by v-Myb. Oncogene 20 231-239, 2001

18. Palamarchuk A, Efanov A, Maximov V, Aqeilan RI, Croce CM and Pekarsky Y: Akt phosphorylates and regulates Pdcd4 tumor suppressor protein. Cancer Res 65: 11282-11286, 2005

19. Mudduluru G, Medved F, Grobholz R, et al: Loss of programmed cell death 4 expression marks adenoma-carcinoma transition, correlates inversely with phosphorylated protein kinase B, and is an independent prognostic factor in resected colorectal cancer. Cancer 110: 1697-1707, 2007.

20. Dorrello NV, Peschiaroli A, Guardavaccaro D, Colburn NH, Sherman NE and Pagano M: S6K1- and betaTRCP-mediated degradation of PDCD4 promotes protein translation and cell growth. Science 314: 467-471, 2006

21. Chen Y, Knosel T, Kristiansen G, et al: Loss of PDCD4 expression in human lung cancer correlates with tumour progression and prognosis. J Pathol 200: 640-646, 2003.

22. Ma G, Guo KJ, Zhang H, et al: [Expression of programmed cell death 4 and its clinicopathological significance in human pancreatic cancer]. Zhongguo Yi Xue Ke Xue Yuan Xue Bao 27: 597-600, 2005 .

23. Gao F, Zhang P, Zhou C, et al: Frequent loss of PDCD4 expression in human glioma: possible role in the tumorigenesis of glioma. Oncol Rep 17: 123-128, 2007.

24. Wang X, Wei Z, Gao F, et al: Expression and prognostic significance of PDCD4 in human epithelial ovarian carcinoma. Anticancer Res 28: 2991-2996, 2008.
25. Gao F, Wang X, Zhu F, et al: PDCD4 gene silencing in gliomas is associated with $5^{\prime} \mathrm{CpG}$ island methylation and unfavorable prognosis. J Cell Mol Med (In press).

26. Jovanovic M and Hengartner MO: miRNAs and apoptosis: RNAs to die for. Oncogene 25: 6176-6187, 2006.

27. Kloosterman WP and Plasterk RH: The diverse functions of microRNAs in animal development and disease. Dev Cell 11: 441-450, 2006.

28. Caldas C and Brenton JD: Sizing up miRNAs as cancer genes. Nat Med 11: 712-714, 2005.

29. Esquela-Kerscher A and Slack FJ: Oncomirs - microRNAs with a role in cancer. Nat Rev Cancer 6: 259-269, 2006.

30. Chan JA, Krichevsky AM and Kosik KS: MicroRNA-21 is an antiapoptotic factor in human glioblastoma cells. Cancer Res 65: 6029-6033, 2005.

31. Roldo C, Missiaglia E, Hagan JP, et al: MicroRNA expression abnormalities in pancreatic endocrine and acinar tumors are associated with distinctive pathologic features and clinical behavior. J Clin Oncol 24: 4677-4684, 2006.

32. Meng F, Henson R, Lang M, et al: Involvement of human micro-RNA in growth and response to chemotherapy in human cholangiocarcinoma cell lines. Gastroenterology 130: 2113-2129, 2006.

33. Meng F, Henson R, Wehbe-Janek H, Ghoshal K, Jacob ST and Patel T: MicroRNA-21 regulates expression of the PTEN tumor suppressor gene in human hepatocellular cancer. Gastroenterology 133: 647-658, 2007.

34. Si ML, Zhu S, Wu H, Lu Z, Wu F and Mo YY: miR-21-mediated tumor growth. Oncogene 26: 2799-2803, 2007.

35. Volinia S, Calin GA, Liu CG, et al: A microRNA expression signature of human solid tumors defines cancer gene targets. Proc Natl Acad Sci USA 103: 2257-2261, 2006.

36. Asangani IA, Rasheed SA, Nikolova DA, et al: MicroRNA-21 (miR-21) post-transcriptionally downregulates tumor suppressor Pdcd 4 and stimulates invasion, intravasation and metastasis in colorectal cancer. Oncogene 27: 2128-2136, 2008.

37. Lu Z, Liu M, Stribinskis V, et al: MicroRNA-21 promotes cell transformation by targeting the programmed cell death 4 gene. Oncogene 27: 4373-4379, 2008.

38. Zhu S, Wu H, Wu F, Nie D, Sheng S and Mo YY: MicroRNA-21 targets tumor suppressor genes in invasion and metastasis. Cell Res 18: 350-359, 2008.

39. Frankel LB, Christoffersen NR, Jacobsen A, Lindow M, Krogh A and Lund AH: Programmed cell death 4 (PDCD4) is an important functional target of the microRNA miR-21 in breast cancer cells. J Biol Chem 283: 1026-1033, 2008.

40. Chen Y, Liu W, Chao T, et al: MicroRNA-21 down-regulates the expression of tumor suppressor PDCD4 in human glioblastoma cell T98G. Cancer Lett 272: 197-205, 2008.

41. Mimori K, Mori M, Shiraishi T, et al: Clinical significance of tissue inhibitor of metalloproteinase expression in gastric carcinoma. Br J Cancer 76: 531-536, 1997.

42. Mori M, Mimori K, Yoshikawa Y, et al: Analysis of the geneexpression profile regarding the progression of human gastric carcinoma. Surgery 131: S39-S47, 2002.

43. Inoue H, Mori M, Honda M, et al: The expression of tumorrejection antigen 'MAGE' genes in human gastric carcinoma. Gastroenterology 109: 1522-1525, 1995.

44. Ogawa K, Utsunomiya T, Mimori K, et al: Clinical significance of elongation factor-1 delta mRNA expression in oesophageal carcinoma. Br J Cancer 91: 282-286, 2004

45. Mantel N: Evaluation of survival data and two new rank order statistics arising in its consideration. Cancer Chemother Rep 50: 163-170, 1966.

46. Zhu S, Si ML, Wu H and Mo YY: MicroRNA-21 targets the tumor suppressor gene tropomyosin 1 (TPM1). J Biol Chem 282: 14328-14336, 2007. 